\title{
GERAKAN LITERASI SEKOLAH DALAM MENUMBUHKAN MINAT BACA SISWA DI SDN SARI KALAMPA
}

\author{
Nunung Fatimah \\ STKIP Taman Siswa Bima \\ Email : nunungfatimah95@gmail.com
}

\begin{abstract}
Abstrak:
Kemampuan berliterasi merupakan salah satu keterampilan dasar yang harus dimiliki oleh Siswa di SDN Sari Kalampa. Gerakan literasi sekolah menjadi sangat penting untuk di maksimalkan dalam mewujudkan minat baca siswa SDN Sari Kalampa. Penelitian ini bertujuan untuk mendapatkan gambaran tentang pelaksanaan gerakan literasi sekolah di SDN Sari Kalampa mulai dari perencanaan, Perangkat Pembelajaran, dan Media Pembelajaran, sebagai upaya untuk meningkatkan keterampilan dasar siswa melalui gerakan literasi. Metode penelitian ini menggunakan rancangan jenis penelitian deskriptif dengan pendekatan kualitatif. Data dalam penelitian ini berupa informasi yang diperoleh dari dokumen tertulis yang terkait langsung dengan pembiasaan, pengembangan dan pembelajaran. Sumber data dalam penelitian ini ialah guru bahasa Indonesia, kepala sekolah, dan siswa SDN Sari Kalampa. Hasil penelitian ini Menunjukan bahwa Perencanaan Gerakan Literasi Sekolah yang dilakukan oleh guru Bahasa Indonesia SDN Sari Kalampa dapat dilihat dari perangkat pembelajaran yang digunakan, seperti silabus, media, dan bahan pembelajaran yang digunakan. Pelaksanaan kegiatan Gerakan Literasi Sekolah (GLS) telah memenuhi tahapan-tahapan literasi di sekolah, antara lain tahap pembiasaan, tahap pengembangan, dan tahap pembelajaran bagi siswa di SDN Sari Kalampa.
\end{abstract}

Kata Kunci: Gerakan Literasi, SDN Sari Kalampa

\section{PENDAHULUAN}

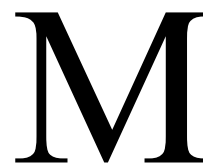

inat baca siswa di Indonesia masih tergolong rendah. Central Connecticut State University melakukan studi Most Littered Nation in the World pada bulan Maret 2016 menunjukkan bahwa minat baca bangsa Indonesia dari 61 negara menduduki peringkat ke-60 (Gewati, 2016). Rendahnya pemahaman siswa tingkat sekolah dasar serta kurangnya pemahaman terhadap literasi informasi, serta pentingnya literasi informasi menimbulkan kekhawatiran pemerintah Indonesia sebagai salah satu pemangku kepentingan pendidikan menjadi penyebab masalah yang 
cukup serius sampai saat ini. Pemerintah dengan segala upayanya berusaha untuk meningkatkan minat baca dan kemampuan literasi membaca untuk anak usia sekolah salah satunya dengan mengeluarkan kebijakan Gerakan Literasi Sekolah.

Literasi merupakan kemampuan membaca, menulis dan berpikir kritis. Melalui literasi diharapkan tumbuh kesadaran kritis untuk mempelajari sesuatu yang baru atau mengasimilasikannya dengan pengetahuan sebelumnya. Dalam fungsinya, literasi mampu memengaruhi pemikiran seseorang, menumbuhkan budaya kritis hingga melahirkan masyarakat yang cerdas dan memiliki daya saing. Berbagai penelitian pun dilakukan untuk mengetahui dan mencari upaya guna meningkatkan budaya literasi di Indonesia. Harapannya adalah dengan tingginya budaya literasi maka Indonesia akan semakin berkembang dan maju, minimal mampu setara dengan negara-negara bandingan. Namun, bagaimana sebenarnya konsep dan realita literasi di Indonesia, hal tersebut rupaya menjadi topik yang cukup menarik di kalangan praktisi pendidikan khususnya ilmu bahasa akhir-akhir ini (Musthafa, 2014).

Gerakan LitersiSekolah merupakan suatu upaya yang dilakukan untuk menciptakan masyarakat yang literat melalui organisasi sekolah. Gerakan Literasi Sekolah tersebut dipayungi oleh Peraturan Mentri Pendidikan Dan Kebudayaan nomor 23 tahun 2015 tentang Penumbuhan BudiPekerti yang menjelaskan bahwa salah satu cara dalam menumbuhkan budi pekerti yaitu dengan mengisi kegiatan membaca buku non pelajaran sebelum pelajaran dimulai selama lima belas menit. Artinya, gerakan tersebut bukanlah berposisi sebagai kegiatan pembelajaran dalam medan intrakurikuler, tetapi Gerakan Literasi Sekolah merupakan kegiatan pembudayaan yang memberikan kontribusi entry behavioryang ditanamkan pada siswa dengan nilai-nilai kemanfaatan dapat memberikan dukungan terhadap kompetensi siswa untuk lancar dan mudah memahami wacana yang terkait dengan mata pelajaran (Khusnul Khotimah'Dkk, 2018)

Gerakan literasi adalah kemampuan mengakses, memahami, dan menggunakan sesuatu secara cerdas melau berbagai aktivitas, antara lain membaca, melihat, menyimak, menulis, dan berbicara (Faizah, dkk 2016:1). Selain itu Literasi merupakan kemampuan membaca dan menulis sehingga perkembangan literasi menjadi sangat penting untuk di perhatikan secara tepat, karena literasi adalah awal yang harus dimiliki oleh setiap orang, 
dengan hadirnya literasi akan menghasilkan kemantangan siswa dalam minat baca yang khusunya pada tahap kelas awal (Yuniati. 2014).

Selaras dengan itu, memilih materi bacaan dari berbagai macam sumber dimaksudkan agar siswa memiliki wawasan yang luas dan menjadikan membaca sebagai kegiatan yang tidak membosankan. Bahan bacaan yang diberikan kepada kelas rendah dan kelas tinggi berbeda. Kelas rendah lebih menyukai bahan bacaan yang mengandung informasi sederhana, bergambar, bersifat inspiratif dan imajinatif, bergenre fantasi fabel, dan mengandung pesan yang sesuai dengan tahap perkembangan peserta didik kelas rendah. Berbeda dengan peserta didik kelas tinggi yang lebih menyukai bacaan dengan informasi kompleks, inspiratif dan imajinatif, bergenre cerita rakyat, dan mengandung pesan moral sesuai dengan tahap perkembangan peserta didik kelas tinggi (Kemendikbud, 2016:10-22).

Salah satu solusi untuk meningkatkan kemampuan membaca dan menulis siswa adalah melalui gerakan literasi sekolah (GLS) dalam peningkatan gerakan literasi siswa di SDN Sari Kalampa Kecamatan Woha Kabupaten Bima, Sebab siswa di SDN Sari Kalampa kemampuan membaca dan menulis masih menjadi permasalahan pokok hal ini dapat dilihat dari perangkat pembelajaran yang digunakan, seperti silabus, media, dan bahan pembelajaran yang digunakan, sehingga gerakan literasi sekolah ini menjadi bahan evaluasi bagi SDN Sari Kalampa dengan demikian siswa akan mampu membaca bahkan dalam menulis sehingga dapat menumbuhkembangkan budaya literasi di sekolah, meningkatkan kapasitas warga dan lingkungan sekolah agar literat, menjadikan sekolah sebagai taman belajar yang menyenangkan dan ramah anak agar warga sekolah mampu mengelola pengetahuan dan menjaga keberlanjutan pembelajaran dengan menghadirkan beragam buku bacaan dan mewadahi berbagai strategi membaca.

\section{TINJAUAN TEORITIS}

\section{Pengertian Gerakan Literasi}

Pengertian Literasi Sekolah dalam konteks GLS adalah kemampuan mengakses, memahami, dan menggunakan sesuatu secara cerdas melalui berbagai aktivitas, antara lain membaca, melihat, menyimak, menulis, dan/ atau berbicara (Kemendikbud, 2016:2). Literasi merupakan suatu 
kemampuan yang dimiliki oleh seseorang yang berkaitan dengan proses memahami informasi, baik melalui membaca atau pun menulis. Sebagian besar keberhasilan proses pembelajaran bergantung pada kemampuan literasi peserta didik. Oleh karena itu, kemampuan literasi ini merupakan langkah penting dalam keberhasilan proses pembelajaran yang efektif. Hal tersebut disebabkan dengan kemampuan literasi yang baik peserta didik memiliki daya kritis dan imajinatif yang baik sehingga dapat menghasilkan ide dan gagasan (Titik Wulandari, 2019).

Literasi sebagai budaya membaca menulis terbukti telah tertanam sejak lama di kebidupan bangsa ini. Secara mendalam, literasi tidak sekadar serangkaian kegiatan mengeja atau menggoreskan lambang bahasa, melainkan ada unsur kebermaknaan di setiap aktivitasnya. Jika mengacu pada uraian tersebut, maka sebenarnya literasi di bangsa ini tidak sekadar membaca dan menulis apa yang tampak. Misalnya, masyarakat percaya akan berbagai fenomena alam yang mampu dibaca dan dituliskan oleh ahlinya. Pembacaan dan penulisan tersebut tidak bisa secara sederhana dinyatakan sebagai mitos, karena masyarakat hingga saat ini percaya dan melakukan berbagai tradisi-tradisi yang ada.

Segala hal yang menjadi pembahasan budaya literasi di masyarakat memang menjadi tanggung jawab semua pihak. Namun, para cendekiawanlah yang seharusnya menjadi prionir untuk melakukan pembenahan diri. Budaya literasi menunjukkan identitas kecendekiawanan sebuah bangsa, untuk itu para cendekiawan pula memiliki peran memberi inspirasi atau teladan bagi masyarakat. Pembenahan tidak hanya dilakukan pada pelaku literasi, perlu adanya wadah yang mampu dijangkau oleh semua pihak dalam menyajikan eksistensi setiap individu atau kelompok. Melalui akar budaya yang telah ada dan komitmen semua pihak untuk meneruskan dan mengembangkan budaya literasi, diharapkan bangsa ini mampu bersaing dengan bangsa lain, menjadi bangsa bermartabat dan utamanya mewujudkan cita-cita bangsa'mencerdaskan kehidupan Bangsa (Augustia Rahma Damayantie, 2015).

\section{Konsep Gerakan Literasi Sekolah (GLS)}

Meningkatkan kemampuan literasi melalui kegiatan menanggapi buku pengayaan, dan Meningkatkan kemampuan literasi di semua mata pelajaran menggunakan buku pengayaan dan strategi membaca di semua mata pelajaran. Dengan adanya masalah ini perlu adanya penanganan yang tepat 
sehingga minat baca siswa dalam literasi akan meningkat dan cara guru harus mampu menciptakan srategi yang tepat agar anak-anak tidak cenderung bosan dan malas dalam pelaksanaan kegiatan literasi (Nunung Fatimah \& Desy Ningsih Komalasari, 2021).

Gerakan Literasi Sekolah ini bertujuan membiasakan dan memotivasi siswa untuk mau membaca dan menulis guna menumbuhkan budi pekerti. Program GLS ini dapat diwujudkan dengan program-program yang mendukung kegiatan literasi di sekolah, antara lain peserta didik membaca buku (selain buku pelajaran) selama lima belas menit sebelum jam pelajaran dimulai, tersedianya fasilitas pojok baca di kelas atau di sekolah guna mendukung kegiatan literasi sekolah,dll. Dengan demikian, gerakan literasi ini dapat membuat siswa memiliki budaya membaca dan menulis sehingga tercipta pembelajaran sepanjang hayat. Dalam jangka panjang, diharapkan dapat menghasilkan anak-anak yang memiliki kemampuan literasi tinggi. Hal ini dikarenakan pada dasarnya dalam kemampuan menulis atau membaca memerlukan sebuah pelatihan yang berulang-ulang (pembiasaan). Berbagai upaya sudah dilakukan oleh pemerintah pusat sebagai pemangku kepentingan di bidang pendidikan. Kemendikbud mengembangkan GLS yang melibatkan lembaga-lembaga pendidikan dari tingkat satuan pendidikan sampai tingkat pusat pendidikan. Kegiatan ini juga harus mendapatkan dukungan dari pihak non-warga sekolah. Peran guru sebagai orang tua di sekolah memiliki peran penting dalam keterlaksanaan program GLS (Faizah, dkk, 2016).

\section{METODE PENELITIAN}

Penelitian ini tergolong jenis penelitian deskriptif dengan pendekatan kualitatif. Penelitian ini bertujuan untuk memperoleh deskripsi tentang pelaksanaan gerakan literasi sekolah (GLS) khususnya berkaitan dengan pembiasaan, pengembangan dan pembelajaran dalam penerapan Gerakan literasi sekolah yang dilaksanakan di SDN Sari Kalampa. Peneliti menentukan rancangan penelitian, rumusan masalah, memilih data dan sumber data, melakukan pengumpulan dan analisis data, dan menyusun laporan penelitian. Dalam penelitian kualitatif instrumen utamanya adalah peneliti sendiri (Sugiyono (2009). Data penelitian ini adalah informasi tentang Gerakan Literasi sekolah yang diterapkan di lingkungan SDN Sari Kalampa. Data dalam penelitian ini berupa informasi yang diperoleh dari 
dokumen tertulis yang terkait langsung dengan pembiasaan, pengembangan dan pembelajaran dan penerapan gerakan literasi sekolah. Sumber data dalam penelitian ini ialah Kepala sekolah, Guru Bahasa Indonesia dan Siswa SDN Sari Kalampa. Sumber data adalah subjek dari mana data dapat diperoleh (Arikunto (2006).

Pengumpulan dilakukan dengan angket, dokumentasi berkaitan dengan pembiasaan, pengembangan dan pembelajaran kegiatan Gerakan Literasi Sekolah SDN Sari Kalampa. Setelah data terkumpul, data diklasifikasikan pembiasaan, pengembangan dan pembelajaran dengan penerapan gerakan literasi sekolah. Peneliti menganalisis dokumen sesuai dengan fokus masalah yang diamati dalam Panduan Analisis Penerapan gerakan lietrasi sekolah dengan menggunakan rubrik panduan. Langkah selanjutnya adalah peneliti menganalisis secara verbal dari hasil chek list. Peneliti menjelaskan hasil chek list secara verbal dengan mengaitkan hasil pengamatan, hasil angket, rubrik panduan, dll. Sebagai pedoman analisis verbal, peneliti menggunakan tolok ukur yaitu refereni dan teori yang berkaitan dengan perencanaan, pelaksanaan, dan evaluasi gerakan literasi sekolah di lingkungan sekolah SDN Sari Kalampa.

\section{HASIL DAN PEMBAHASAN}

Gerakan Literasi Sekolah (GLS) adalah gerakan sosial kolaboratif dengan dukungan berbagai elemen pendidikan. Hal ini menunjukkan bahwa dalam kegiatan Gerakan Literasi Sekolah (GLS) melibatkan warga sekolah (siswa, guru, kepala sekolah, orang tua) dan masyarakat (Kemendikbud (2016:7). Hasil penelitian menunjukan bahwa pelaksanaan gerakan literasi sekolah (GLS) di SDN Sari Kalampa telah mampu menumbuhkan minat baca siswa dengan program gerakan literasi sekolah (GLS) melalui pemanfaatan sudut baca yang terdapat di setiap kelas. Berdasarkan penelitian ini saran yang dapat disampaikan adalah pelaksanaan gerakan literasi sekolah (GLS) di SDN Sari Kalampa hendaknya pihak sekolah meningkatkan kerja sama dengan orang tua, masyarkat sekitar dan pemangku kepentingan lain untuk menumbuhkan minat baca siswa.

Pengembangan dan penataan perpustakaan kelas, dan area baca menjadi penting dari pelaksanaan GLS di SD dan pengelolaan pengetahuaan yang berbasis pada bacaan. Tempat literasi yang dikelola dengan baik mampu meningkatkan minat baca dan mampu menjadikan warga sekolah 
sebagai pembelajaran sepanjang hayat. Pelaksanaan kegiatan membaca 15 menit dilakukan dengan menggunakan metode membaca nyaring dan membaca dalam hati. Membaca nyaring pada kelas rendah, khususnya kelas I dilakukan melalui kegiatan membaca buku dengan suara lantang secara bergantian di depan kelas. Sementara siswa kelas II dan kelas III sudah mulai mampu membaca secara mandiri dengan metode membaca senyap (membaca di dalam hati). Membaca senyap dilakukan dengan cara menyampaikan poin-poin buku di jurnal baca yang sudah diisi. Kelas tinggi melakukan kegiatan membaca secara mandiri dengan memilih buku bacaan di sudut baca kelas atau yang telah dibawa dari rumah sesuai pilihan masingmasing. Pada kelas tinggi kegiatan membaca fokus pada kegiatan apresiasi sastra, seperti membaca, menulis dan diskusi tentang puisi, cerpen, pantun dan karya sastra lain. Selain itu pelaksanaan literasi diterapkan melalui program berkarya seni dan sastra. Program berkarya seni dan sastra siswa dilakukan melalui mengisi mading di setiap kelas dengan hasil karya siswa sendiri baik berupa gambar, puisi maupun pantun sederhana (Febriana Ramandanu, 2019:13).

Namun terobosan penting ini hendaknya melibatkan semua pemangku kepentingan di bidang pendidikan, mulai dari tingkat pusat, provinsi, kabupaten/kota, hingga satuan pendidikan yaitu sekolah. Pelibatan orang tua peserta didik dan masyarakat juga menjadi komponen penting dalam keberhasilan Gerakan Literasi Sekolah (GLS) (Syaifur Rohman, 2017). Gerakan Literasi Sekolah (GLS) di SDN Sari Kalampa telah mencakup aspek pembiasaan, pengembangan dan pembelajaran. Hal ini terlihat dari Perencanaan gerakan literasi sekolah oleh guru Bahasa Indonesia dapat dilihat dari perangkat pembelajaran yang digunakan, yaitu RPP, silabus, media, dan bahan pembelajaran yang ada.Pelaksanaan kegiatan Gerakan Literasi Sekolah (GLS) SDN Sari Kalampa telah memenuhi tahapantahapan literasi di sekolah, antara lain tahapan pembiasaan, tahapan pengembangan, dan tahapan pembelajaran dengan penjelasan sebagai berikut:

\section{Tahapan Pembiasaan}

Kegiatan pada tahapan pembiasaan yang telah dilakukan SDN Sari Kalampa telah memenuhi indikator tahapan pembiasaan hal ini terlihat berdasarkan angket pelaksanaan Gerakan Literasi Sekolah, yaitu angket yang diberikan pada guru, waka kurikulum, petugas perpustakaan, guru 
Bahasa Indonesia, dan siswa menunjukan bahwa memenuhi indicator, seprti ada kegiatan 15 menit membaca. Membaca 15 Menit Sebelum Pelajaran Dimulai yang dilakukan oleh Guru/pustakawan/kepala SD/relawan membacakan buku/bahan bacaan lain dengan nyaring. Tujuannya adalah memotivasi peserta didik agar mau membaca; membuat peserta didik dapat membaca dan gemar membaca, memberikan pengalaman membaca yang menyenangkan, membangun komunikasi antara guru dan peserta didik guru/pustakawan/kepala sekolah menjadi teladan membaca (Kemendikbud, 2016:10).

\section{Tahapan Pengembangan}

Kegiatan literasi pada tahap pengembangan bertujuan untuk mempertahankan minat terhadap bacaan dan terhadap kegiatan membaca, serta meningkatkan kelancaran dan pemahaman membaca peserta didik. Berdasarkan angket pelaksanaan kegiatan literasi Tahap Pengembangan meliputi kegiatan lima belas menit membaca di awal atau akhir pembelajaran di SDN Sari Kalampa seperti Guru membacakan buku/ bahan bacaan dan mengajak peserta didik untuk menyimak dan menanggapi bacaan dengan aktif. Proses membacakan buku ini bersifat interaktif karena guru memeragakan bagaimana berpikir menanggapi bacaan dan menyuarakannya (think aloud) dan mengajak peserta didik untuk melakukan hal yang sama. Fokus kegiatan membacakan nyaring interaktif biasanya adalah untuk memahami kosa kata baru. Kegiatan pada tahapan pengembangan yang telah dilakukan di SDN Sari Kalampa antara lain siswa membuat catatan baik dalam ringkasan/rangkuman, dapat diketahui bahwa setiap siswa SDN Sari Kalampa mempunyai kegiatan literasi sekolah bagi Siswa SDN Sari Kalampa.

\section{Tahapan Pembelajaran}

Kegiatan literasi pada tahap pembelajaran bertujuan untuk mempertahankan minat peserta didik terhadap bacaan dan terhadap kegiatan membaca, serta meningkatkan kecakapan literasi peserta didik melalui buku-buku pengayaan dan buku teks pelajaran. Kecakapan Literasi di SD Kegiatan literasi pada tahap pembelajaran meningkatkan kemampuan berbahasa reseptif (membaca dan menyimak) dan aktif (berbicara dan menulis) yang dijelaskan secara rinci dalam konteks dua kegiatan utama di tahap ini, yaitu membaca dan menulis. Kemampuan membaca dan menulis 
dijenjangkan agar peningkatan kecakapan di empat area berbahasa tersebut (membaca, menyimak, berbicara, dan menulis) dapat dilakukan secara terukur dan berkelanjutan. Jenjang kemampuan membaca dan menulis dibagi dalam tiga tingkatan: awal, pemula, dan madya, yang merentang dari SD kelas rendah ke kelas tinggi (Kemendikbut, 2016).

Kegiatan literasi sekolah yang dilakukan SDN Sari Kalampa pada tahap pembelajaran antara lain kegiatan membaca setiap hari; guru dan peserta didik melakukan kegiatan literasi disertai tagihan akedemik dan atau nonakademik; dilaksanakan berbagai kegiatan tindak lanjut oleh pelaksana kegiatan literasi, baik secara tagihan lisan dan tulisan yang digunakan sebagai evaluasi akademik; pemanfaat beragam bacaan untuk kegiatan literasi; dan kepala perpustakaan sekolah menyediakan buku bacaan yang bervariasi (buku- buku nonpelajaran (Hasil Wawancara Dengan Ibu Supriati Selaku Kepala Sekolah SDN Sari Kalampa).

Kegiatan literasi yang termasuk dalam Dimensi Kesadaran yang telah dilakukan dalam pembelajaran antara lain siswa melakukan diskusi bersama teman saat merangkum buku, siswa merefleksikan bacaan yang telah dibaca dan menjelaskan kembali kepada guru dan teman lainnya pada saat pelaksanaan gerakan literasi dalam kegiatan pembelajaran. Perencanaan penggunaan bahan dan media pembelajaran dalam gerakan literasi sekolah sudah ada Guru merencanakan penggunaan bahan ajar dan media pembelajaran dalam kaitannya kegiatan literasi sekolah. Media pembelajaran yang digunakan dalam pembelajaran dapat berpengaruh terhadap efektivitas pembelajaran, hal tersebut dapat disebabkan dengan adanya media dapat mengatasi keterbatasan pengalaman yang dimiliki peserta didik (Sadiman, 2010). Penggunaan bahan ajar dan media pembelajaran juga dapat dilihat pada aspek pelaksanaan gerakan literasi sekolah, yaitu guru mata pelajaran Bahasa Indonesia sebagian besar menggunakan bahan ajar dan media pembelajaran antara lain komputer, internet, power poin, majalah, jurnal, cerpen, novel, dll. Pemanfaatan media pembelajaran dalam pembelajaran tersebut diharapkan dapat menjadikan pembelajaran yang inovatif dan kreatif, dapat menarik perhatian dan minat siswa. Bahan ajar dan media pembelajaran yang digunakan guru dalam perencanaan kegiatan literasi sekolah tersebut disesuaikan dengan materi yang diajarkan, dan juga sesuai dengan tingkat kebutuhan peserta didik. 
Penggunaan media dalam berbagai bentuk sangat bermanfaat dalam proses pengajaran (Nababan, 1993:215).

\section{SIMPULAN}

Berdasarkan temuan penelitian ini dapat disimpulkan bahwa kegiatan Gerakan Literasi Sekolah (GLS) dalam menumbuhkan minat baca siswa SDN Sari Kalampa, secara umum tidak berjalan dengan maksimal dalam kegiatan pembiasaan, pengembangan dan pembelajaran dalam kegiatan gerakan literasi sekolah sesuai Panduan Gerakan Literasi Sekolah di Sekolah Dasar. Hal ini disebabkan oleh Kegiatan Literasi Sekolah (GLS) di SDN Sari Kalampa Kecamatan Woha Kabupaten Bima belum menggunakan penilaian secara menyeluruh. Penilaian dan evaluasi atas kegiatan literasi sekolah masih difokuskan pada pencatatan hasil kegiatan literasi sekolah saja yang dilakukan oleh guru Bahasa Indonesia dan pendamping. Sebagai evaluasi dalam penelitian ini Kepala sekolah perlu koordinasi dengan para guru dalam menyusun penilaian tindak lanjut. Harapannya penilaian Gerakan Literasi Sekolah (GLS) SDN Sari Kalampa tidak hanya dilakukan hanya oleh guru Bahasa Indonesia, tetapi semua pihak sekolah sehingga dapat diwujudkan penilaian yang menghasilkan tindak lanjut (tidak hanya berakhir pada penghargaan). Kurangnya aktif dari siswa dalam memanfaat fasilitas sekolah berkaitan dengan gerakan literasi sekolah, termasuk fasilitas perpustakaan, pojok baca di kelas atau di sekolahan. Selain itu, siswa aktif mencari informasi berkaitan dengan kegiatan di luar sekolah sehingga dapat menambah pengetahuan literasi siswa.

\section{DAFTAR PUSTAKA}

Arikunto, S. 2006. Prosedur Penelitian: Suatu Pendekatan Praktik. Jakarta: Rineka Cipta, Hal 129

Augustia Rahma Damayantie (2015) Literasi Dari Era Ke Era, Jurnal UPGRI Semarang, Hal 9

Faizal, Dewi Utama, (2016) Panduan Gerakan Literasi Sekolah Di Sekolah Dasar. Jakarta: Direktorat Pembinaan Sekolah Dasar

Febriana Ramandanu (2019) Gerakan Literasi Sekolah (Gls) Melalui Pemanfaatan Sudut Baca Kelas Sebagai Sarana Alternatif Penumbuhan Minat Baca Siswa, Jurnal Mimbar Ilmu, Vol. 24 No. 1, 2019

Gewati, M, (2016), Minat Baca Indonesia Ada di Urutan Ke-60 Dunia (Online), di akses pada tanggal 15 Agustus 2021 
Khusnul Khotimah' Dkk, (2018), Pelaksanaan Gerakan Literasi Sekolah, Jurnal Pendidikan; Teori, Penelitian, dan Pengembangan Volume: 3 Nomor: 11 Bulan November Tahun 2018, Hal 2

Kemendikbud, (2016) Panduan Gerakan Literasi Sekolah di Sekolah Dasar, Direktorat Pembinaan Sekolah Dasar Direktorat Jenderal Pendidikan Dasar Dan Menengah Kementerian Pendidikan Dan Kebudayaan Tahun 2016

Musthafa, Bachrudin (2014) Literasi Dini dan Literasi Remaja: Teori, Konsep

Praktik. Bandung: CREST, Hal 7

Nunung Fatimah \& Desy Ningsih Komalasari, (2021) The Development of Big Book Media as a Local Solution for the Student Literacy Movement of Inpres Sambori Elementary School Lambitu District Bima Regency, Atlantis Press, Proceedings of the 2nd Annual Conference on Education and Social Science (ACCESS 2020) Hal 3

Nababan, S.U.S, (1993) Metodologi Pengajaran Bahasa, Jakarta: Gramedia PustakaUtama, Hal 215.

Sadiman, A.S. 2010. Media Pendidikan. Jakarta: RajaGrafindo Persada, Hal 10

Sugiyono, (2006) Metode Penelitian Pendidikan: Pendekatan Kuantitatif, Kualitatif, dan R\& D. Bandung: Alfabeta, Hal 307

Syaifur Rohman (2017) Membangun Budaya Membaca Pada Anak Melalui Program Gerakan Literasi Sekolah, TERAMPIL: Jurnal Pendidikan dan Pembelajaran Dasar Volume 4 Nomor 1 Juni 2017

Titik Wulandari, (2019) Pelaksanaan Gerakan Literasi Sekolah di SMA Negeri 5 Malang, Jurnal NOSI, Volume 7 Nomor 2 Tahun 2019 Hal 2

Yuniati, (2014) Keterampilan Membaca Permulaan Melalui Media Big Book Siswa Kelas IB SDN Mangiran Kecamatan Srandakan, Universitas Negeri Yogyakarta 